\title{
Measuring customer's credit risk in banking industry
}

\author{
Hassan Ghodrati* and Hassan Abyak
}

Department of Management and Accounting, Kashan Branch, Islamic Azad University, Kashan, Iran

\begin{tabular}{l}
\hline C H R O N I C L E \\
\hline Article history: \\
Received January 18, 2013 \\
Received in revised format \\
2 June 2013 \\
Accepted 5 June 2013 \\
Available online \\
June 10 2013 \\
\hline Keywords: \\
Credit Risk \\
Credit Assessment \\
Linear Regression Model \\
Logit Regression Model
\end{tabular}

\section{Introduction}

The grant of facilities relies on the capability of the applicants for the repayment of such facilities to reduce the probability of the nonpayment of the facilities. The evaluation of customer credit are carried out by an accredited expert; but this is a cost-consuming process because of insufficient time, qualified personnel, and high prices. In recent years, many studies have been carried out to find an effective method for rating and determining the credit risk of the applicant of facilities. Maury is believed to be the first who designed for the first time a model for the assessment of credit risk of bonds (Tehrani \& Shams). Thereafter, this issue has been studied in various financial fields. The deferred receivables of banks may be the origin of monetary and financial crises, and their adverse effects may endanger various economic and manufacturing fields. Recently, after the monetary and

*Corresponding author.

E-mail addresses: dr.ghodrati42@yahoo.com (H. Ghodrati) 
financial crises of 2008 in the USA that had its roots in the increase in banks deferred receivables leading to the bankruptcy of many American banks, other banks remained intact were warned.

The increase in the ratio of the deferred receivables to the facilities granted by Iranian banks made the central bank of Iran to pay special attention to this issue. Considering the causes of banks' deferred receivables having the root in banks' inter-organizational weaknesses and many other external factors have been provided to reduce such deferred receivables. The enhancement of risk management in banks, identification and coverage of all risks, accurate evaluation of designs together with the qualitative and quantitative improvement of financial, technical, and economic studies and evaluation of the financial ability of the applicants and the guarantors of the repayment of facilities in addition to the use of intra- and extra-organizational experts.

The accelerated growth of banking industry, privatization of public banks in Iran, and the competition for profitability need that traditional methods are substituted by modern ones. As more than eighty percent of the income of banks and financial institutes is supplied by credit and facilities sector, it is required to substitute traditional methods by modern systematic methods of credit rick forecast to preserve the competitive status of the organization in the market.

\section{Review of Literature}

Rasoulzadeh (2008) used Altman's model to evaluate the companies in the stock exchange from 1996 to 1999. Altman's model was able to give a correct forecast by 75 percent (Sabzevari, 2009). Soltani (2000) studied the impacts of facilities, inflation rate, financial and personal particulars of loan applicants on the deferred receivables of Bank Melli of Mazandaran province. For this purpose, 155 cases of deferred receivables of the period over the period 1981-1999 were implemented to provide regression model. The results showed that there was a significant relation between the type of facilities, personal particulars, properties and real estates, financial power of the company and legal entities and the deferred receivables of the bank (Zekavat, 2003).

Ghasemi Seighalsarai (2000) argues that the coefficient of the correlation between Altman index and repayment of loan is significant at the probability level of 99 percent. It has been also found that the evaluation of the ability to repay the facilities granted by banks depends on the analysis of the ratio of profitability and liquidity, and not on the ratios of activity and debt ratios (Fallah Shams, 2005).

Mansouri and Azar (2002) classified the customers of Bank Mellat into two groups and found according to his study that neural network model used to estimate credit risk was similar to logistic regression with the accuracy of 87.6 percent; but Logit regression has been more efficient in the determination of credit capacity that linear regression is. Other investigation considered the obstacles limiting the use of credit facilities and showed that 70 percent of the studied population considered the rules and regulations of guarantee or contribution in cash as the obstacles of receiving financial facilities and argues that 94 percent of the longtime of processing is itself a difficulty (Fallah Shams, 2005). Zekavat (2003) showed in his unpublished master dissertation that there is no credit risk index in the monetary and financial markets of Iran to cover credit risk. Based on his theoretical and documentary studies, he introduced an audit analysis model and Logit regression model using 4 explanatory variables for the forecast of credit risk.

Fathi (2004) studied the models used for the assessment of bank customer' credit, and provided a table, in which the application method and explanations of audit analysis model, logical regression model, linear planning model, and decision tree method have been provided (Sabzevari, 2009). Vedadi (2004) introduced a model using artificial intelligence for the forecast of credit behavior of customers of Bank Maskan (Housing Bank), and classified the customers into three types of good at settling accounts, tardy at settling accounts, and customers with overdue debts. Thereafter, the variables affecting the behavior of customers have been identified, and after the design of credit rating 
model, this model has been compared with the audit analysis model. In conclusion, it has been found that the rating models of neural networks can forecast more accurately than audit analysis model do.

Latifi (2004) studied the credit indices that are most correlated with the repayment of the debts of customers. For this purpose, the researcher used the credit and financial data of 145 manufacturing companies of Tehran that used bank facilities over the period 1999-2003, and applied Spearman statistic method and audit analysis to study the relation between financial ratios and fulfillment of customers' obligations. Gholamali (2005) studied the manufacturing companies, whose shares are not negotiable, and those ones that received facilities from Bank Sepah. He concluded that Altman index can forecast the non-repayment of facilities better than the financial ratios, which are used for the prediction of companies' cease of activities, do (Heidarzadeh, 2008).

Gharni (2005) implemented Ohlson's model for the study of the companies during the period from 1996 to 2002. He showed that there is a significant relation between financial ratios and the forecast of the cease of corporate activities (Khani, 2007). Fallah (2005) implemented the credit and financial information of 316 legal entities, who were customers of banks, to compare the efficiency of Logit linear probability models and artificial neural networks. He showed that neural networks forecast credit risk with the accuracy of 97 percent, and Logit model with the accuracy of 95 percent.

Khaleghi (2005) evaluated the impact of the interest of the bank facilities paid to the agricultural sector and fixed investment of the government in agricultural sector. He showed that the interest of the facilities paid to the agricultural sector, the ratios of current debt to sales, bank loan to the total debts, net profit to sales, current assets to current debts, current assets to the total assets, sales to the total assets have significant effects on the credit risk (Khani, 2007). Dashti (2007) implemented neural networks to study the optimal allocation of resources and promotion of the quality of bank facilities of Iran. He concludes that the credit rating models of neural networks can forecast better than audit analysis model does. Khani (2007) implemented a sample consisting of 374 legal entities acting as the bank customers of Iran to test the efficiency of linear probability model. The results of this research show that the relation among the variables used to forecast credit risk is not of linear type, and sigmoid functions are the best models for the forecast of credit risk. Heidarzadeh (2008) showed that bankruptcy can be forecasted using the financial ratios of Altman model; but there is no linear relation among independent variables. Moreover, the data of the one year to two years ago can be used to predict bankruptcy.

Sabzevari (2009) implemented two methods of Logit regression and AHP in his unpublished master dissertation titled "the estimation and comparison of Logit credit rating model and AHP hierarchical analysis method". This research has been conducted on the customers of a bank for the period from 2002 to 2004. Among them, 46 customers have been classified as good at settling account, and 40 ones as tardy in settling account. Finally, the researcher concluded that AHP is up to 5 percent more accurate than logit model is. Moreover, in AHP method, it was required that the customers of a specified industry are separated and compared with the ratios of that industry. In the final regression model developed by Sabzevari (2007), the following ratios can be observed: cash to total assets, debts to total assets, retained profit to total assets, bank short-term loans to current debts.

In 1909, John Moody presented for the first time a model for the measurement and rating of credits in relation to bonds. Nowadays, rating institutes such as $\mathrm{S} \& \mathrm{P}$, and Moody's use their own methodologies and credit tools for rating bonds. The close similarity between bank facilities and bonds caused that some researchers pay attention to the rating of credit risk of bank facilities.

In 1936, Fisher developed the fundamentals of credit rating and the first evaluation system of credit application. He used five empirical criteria including professional status, income statement, financial statement (balance sheet), guarantees, and information on the repayment of the facilities paid by 
banks, to study the capabilities of different groups in a statistical population composing of factory owners.

Dourand (1941) implemented audit analysis to study statistically the parameters considered important by the providers of facilities. The obtained results were compared with the results of Fisher. This study improved the theoretical framework used to determine the importance of credit parameters. Therefore, Dourand is considered the founder of credit rating system. In the system used for rating the applicants of loans, he used parameters such as occupation, years of work in this occupation, years of residing at the present address, bank accounts, life insurance policies, and saving accounts, gender, and monthly installments payable at present. Bogess (1961) combined multivariate statistical tools leading to the approval of credit rating in the United Stated of America.

Altman (1968) used audit analysis method to evaluate 66 American manufacturing companies for the period from 1946 to 1965, and obtained resources for the classification of companies in terms of credit risk. For this purpose, he selected 22 financial ratios that were potentially appropriate for his research. These variables were classified into five groups of liquidity, profitability ratio, leverage ratio, debt solvency, and turnover. He showed that assets turnover play the most important role in audit analysis function.

The other study showed that credit risk reduces bank profit. He used the concept of Granger cause to study the temporal relation between facilities and return on cost, and concluded that the long term of repayment of facilities causes that banks increase the costs of supervision, calculations, or sales of loans. Credit risk has been recognized recently as the main reason of the bankruptcies of banks, and one of the most significant risks in bank management.

Lopez (2009) used panel data (combinatory data) and found that the evaluation of credit risk models is always different from that of market risk, and this is due to time horizon. They provided the quantitative models of sensitivity analysis as the most important models for the evaluation of credit risk. Ferrich (1999) and Loner implemented likelihood test and Carlo simulation to show that these tests have a satisfactory power. They also showed that if correlation of dishonor increases, the probability of suffering from losses increases accordingly; but this probability is immaterial.

Hovin and Kelimbar (2006) used 56,037 cases of facilities granted by commercial banks in 2005 to develop their own model of estimation. They selected 22 independent variables such as applicant's annual income, level of facilities, bank account annual average, and rate of loan and interest. Their findings demonstrated that there was a significant relation between the application of credit rating models in commercial fields and the ratio of granting loan. Pasiouras (2008) studied the effect of credit risk, off-balance sheet activities, and international operations" by taking into account variables and indicators that explain banking risks such as default loans as input variables in the DEA, tried to explain the correlation between risk and efficiency in banking industry and found a significant correlation between these two categories.

\section{Research Hypothesis}

\section{Main Hypothesis}

It is more useful to use Logit model for the prediction of credit risk in research field.

\section{Secondary Hypotheses}

1- Liquidity ratios are the most effective factors for the prediction of credit risk of facilities in the field of research.

2- The results of applying linear probability model and Logit model used for the prediction of credit risk in research field are different from each other. 
3- The results of applying logit model for the prediction of credit risk in research field are more consistent with reality.

\subsection{Research Method}

This is an applied research in terms of objective, and use of existing models and methods. For collecting data and inference, it uses descriptive method, and for the generalization of the results to the statistical population, an inductive method is used. Moreover, as in this research operating data of the past times are used, this is an ex post facto study.

\section{A) Statistical Population and sample}

The statistical population of this research consists of the customers with the following characteristics:

- Legal entities that have used the facilities provided by Bank Mellat for the fields of industry and manufacture, their granted facilities have been approved in one of the six branches of Bank Mellat in Tehran, and provided to them in 2009. The facilities had to be repaid at most within one year.

Our sample consisting of 176 bank customers, who are legal entities, has been determined using Morgan's table and based on simple random sampling method.

\section{B) Data Analysis Method}

1) For the analysis of data, the sample has been described using central indices (median, mean, mode, etc.), indices of dispersion (standard deviation, variance, skewness, etc.), correlation, and frequency distribution of parameters.

2) In this research, basic tests including variable normality test, tendency of the coefficient of variation to 1 , linear independence of variables, equality or stability of variances, and normality of residual distribution have been applied to study if the models used for the statistical sample have necessary and sufficient conditions.

3) Significance test of correlation and estimated coefficients of regression equation have been used to generalize the results to the sample.

\section{C) Research Model}

This research aims to study the linear regression model and Logit model comparatively. The general model of this research is as follows: $\mathrm{Y}=f\left(x_{1}, x_{2}, \ldots, x_{20}\right)$

In this mode, $\mathrm{Y}$ is the dependent variable and indicates credit risk. Twenty independent variables effective in the prediction of credit risk are as follows:

$\mathrm{X}_{1}=$ the ratio of cash to total assets, $\mathrm{X}_{2}=$ the ratio of (inventory - current asset) to current debt, $\mathrm{X}_{3}=$ the ratio of current assets to total asset, $\mathrm{X}_{4}=$ the ratio of cash to total assets, $\mathrm{X}_{5}=$ the ratio of current assets to current debt, $\mathrm{X}_{6}=$ the ratio of total debt to total assets, $\mathrm{X}_{7}=$ the ratio of net profit to sales, $\mathrm{X}_{8}$ $=$ the ratio of net profit to total assets, $X_{9}=$ the ratio of net profit to equity, $X_{10}=$ the ratio of retained profit to total assets, $X_{11}=$ the ratio of equity to total assets, $X_{12}=$ the ratio of total bank loan to total assets, $\mathrm{X}_{13}=$ the ratio of total bank loan to total debts, $\mathrm{X}_{14}=$ the ratio of sales to total assets, $\mathrm{X}_{15}=$ the ratio of inventory to sales, $X_{16}=$ the ratio of creditors to sales, $X_{17}=$ the ratio of current debts to sales, $\mathrm{X}_{18}=$ the ratio of total debts to equity, $\mathrm{X}_{19}=$ the ratio of net profit to the costs in bank loan interest, $\mathrm{X}_{20}=$ the ratio of sales to 360 . 
Moreover, $\mathrm{f}$ or function is calculated firstly by simple linear regression, and secondly by logistic regression method using the following equation:

$$
p_{i}=\pi_{i}\left(x_{1}, x_{2} \ldots x_{n}\right)=\frac{e^{\mathrm{B}_{0}+\sum_{i=1}^{n} \mathrm{~B}_{i} x_{i}}}{1+e^{B_{0}+\sum_{i=1}^{n} b_{i} x_{i}}}
$$

\section{Research Founding}

The statistical sample of this research consists of 176 companies, which received facilities from Bank Mellat from Mar. 20, 2008 up to Mar. 20, 2009.

From these companies, 109 ones have been classified as the ones good at settling accounts, and 67 companies as the ones tardy in settling accounts. Thereafter, the financial ratios of each company have been calculated and analyzed.

\section{A) Description of Data}

In the Table 1, the findings have been provided based on the goodness or tardiness in settling accounts.

\section{Table 1}

The Findings based on the Customers

\begin{tabular}{lcccc}
\hline Indices & \multicolumn{2}{c}{ Good at Settling Accounts } & \multicolumn{2}{c}{ Tardy in Settling Accounts } \\
& Mean & Deviation from Standard & Mean & Deviation from Standard \\
\hline Cash to total assets & 0.06 & 0.07 & 0.03 & 0.04 \\
(inventory - current asset) to current debt & 1.67 & 1.14 & 1.29 & 0.86 \\
current assets to total asset & 0.71 & 0.21 & 0.61 & 0.22 \\
cash to total assets & 0.10 & 0.12 & 0.05 & 0.06 \\
current assets to current debt & 1.30 & 0.69 & 0.90 & 0.43 \\
total debt to total assets & 0.70 & 0.26 & 0.90 & 0.33 \\
net profit to sales & 0.14 & 0.21 & 0.00 & 0.21 \\
$R O A$ & 0.12 & 0.17 & 0.00 & 0.10 \\
$R O E$ & 0.42 & 0.47 & 0.21 & 0.64 \\
retained profit to total assets & 0.16 & 0.21 & -0.07 & 0.31 \\
Assets to debt & 0.70 & 0.90 & 0.26 & 0.51 \\
total bank loan to total assets & 0.22 & 0.20 & 0.35 & 0.25 \\
loan to debts & 0.30 & 0.27 & 0.40 & 0.25 \\
sales to total assets & 1.38 & 1.21 & 0.73 & 0.83 \\
inventory to sales & 0.40 & 0.68 & 0.49 & 0.70 \\
creditors to sales & 0.21 & 0.22 & 0.15 & 0.16 \\
current debts to sales & 1.32 & 1.76 & 2.13 & 2.36 \\
total debts to equity & 5.94 & 12.70 & 5.54 & 15.00 \\
net profit to the costs in bank loan interest & 13.83 & 28.69 & 2.69 & 13.54 \\
sales to 360 & 732.67 & 1280.85 & 414.32 & 934.76 \\
\hline
\end{tabular}

\section{B) Normality}

In this research, chi-square test has been applied to evaluate the normality of data, and they are classified and tested based on this test. According to the calculations, the normality of data has been rejected at the confidence level of 95 percent. The logarithm of the dependent variable has been recalculated, and normality test has been carried out. As the significance level is equal to 0.492 and greater than 0.05 , therefore it is proved that the data are distributed normally. 


\section{C) The Relation among Variables based on the Simple Linear Regression Method}

In this research, the estimated model has been finalized after six steps using stepwise method. The determination coefficient has been equal to 0.436 in final step. This means that 44 percent of the changes of dependent variable can be justified by independent variables. Durbin-Watson statistic is equal to 1.8, and determination coefficient is very low. Moreover, 14 insignificant variables have been deleted from the model. The estimated model has been summarized in the Fig. 2.

Table 2

The Estimated Model Finalized based on Simple Linear Regression

\begin{tabular}{|c|c|c|c|c|c|c|c|}
\hline Model & Parameters & Coefficient & $\begin{array}{l}\text { Deviation from } \\
\text { Standard }\end{array}$ & $\begin{array}{l}\text { Standardized } \\
\text { Coefficient }\end{array}$ & $\begin{array}{c}\mathrm{T} \\
\text { value }\end{array}$ & $\begin{array}{c}\text { Significance } \\
\text { Level }\end{array}$ & VIF \\
\hline \multirow[t]{2}{*}{1} & (Constant) & 4.74 & 0.20 & & 23.75 & 0.00 & \\
\hline & Sales to assets & -0.78 & 0.13 & -0.45 & -5.81 & 0.00 & 1.00 \\
\hline \multirow[t]{3}{*}{2} & (Constant) & 4.94 & 0.19 & & 26.00 & 0.00 & \\
\hline & Sales to assets & -0.79 & 0.12 & -0.45 & -6.32 & 0.00 & 1.00 \\
\hline & Net profit to sales & -3.16 & 0.66 & -0.34 & -4.77 & 0.00 & 1.00 \\
\hline \multirow[t]{4}{*}{3} & (Constant) & 5.20 & 0.20 & & 25.67 & 0.00 & \\
\hline & Sales to assets & -0.78 & 0.12 & -0.45 & -6.45 & 0.00 & 1.00 \\
\hline & Net profit to sales & -2.55 & 0.67 & -0.28 & -3.79 & 0.00 & 1.10 \\
\hline & $\begin{array}{l}\text { Cash to current } \\
\text { assets }\end{array}$ & -4.05 & 1.33 & -0.22 & -3.04 & 0.00 & 1.10 \\
\hline \multirow[t]{5}{*}{4} & (Constant) & 5.58 & 0.25 & & 22.27 & 0.00 & \\
\hline & Sales to assets & -0.89 & 0.13 & -0.51 & -7.04 & 0.00 & 1.15 \\
\hline & Net profit to sales & -3.00 & 0.69 & -0.32 & -4.38 & 0.00 & 1.18 \\
\hline & $\begin{array}{l}\text { Cash to current } \\
\text { assets }\end{array}$ & -3.61 & 1.32 & -0.20 & -2.73 & 0.01 & 1.12 \\
\hline & Current debt to sales & -0.17 & 0.07 & -0.19 & -2.49 & 0.01 & 1.22 \\
\hline \multirow[t]{6}{*}{5} & (Constant) & 5.39 & 0.26 & & 20.75 & 0.00 & \\
\hline & Sales to assets & -0.87 & 0.13 & -0.50 & -6.92 & 0.00 & 1.15 \\
\hline & Net profit to sales & -2.97 & 0.67 & -0.32 & -4.40 & 0.00 & 1.18 \\
\hline & $\begin{array}{l}\text { Cash to current } \\
\text { assets }\end{array}$ & -3.42 & 1.30 & -0.19 & -2.62 & 0.01 & 1.12 \\
\hline & Current debt to sales & -0.16 & 0.07 & -0.18 & -2.48 & 0.01 & 1.22 \\
\hline & Debts to equity & 0.02 & 0.01 & 0.16 & 2.33 & 0.02 & 1.01 \\
\hline \multirow[t]{7}{*}{6} & (Constant) & 6.20 & 0.44 & & 14.08 & 0.00 & \\
\hline & Sales to assets & -0.81 & 0.13 & -0.47 & -6.47 & 0.00 & 1.20 \\
\hline & Net profit to sales & -2.64 & 0.68 & -0.28 & -3.89 & 0.00 & 1.24 \\
\hline & $\begin{array}{l}\text { Cash to current } \\
\text { assets }\end{array}$ & -3.46 & 1.28 & -0.19 & -2.70 & 0.01 & 1.12 \\
\hline & Current debt to sales & -0.16 & 0.06 & -0.19 & -2.55 & 0.01 & 1.22 \\
\hline & Debts to equity & 0.03 & 0.01 & 0.18 & 2.74 & 0.01 & 1.05 \\
\hline & $\begin{array}{l}\text { Current assets to } \\
\text { total assets }\end{array}$ & -1.34 & 0.59 & -0.16 & -2.26 & 0.03 & 1.13 \\
\hline
\end{tabular}

The estimated model obtained in the sixth step is as follows:

$$
\operatorname{Ln}(Y)=6.2-0.8 X_{1}-2.6 X_{2}-3.5 X_{3}-0.2 X_{4}+0.03 X_{5}-1.3 X_{6}
$$

\section{D) Estimation of Logit Model}

As mentioned, the previous stepwise method has been applied to develop an appropriate model based on the following Table 3. 
Table 3

The Coefficients of Variables for Logit Model

\begin{tabular}{ccccccc}
\hline Variables & Coefficient & $\begin{array}{c}\text { Deviation from } \\
\text { Standard }\end{array}$ & Parent & $\begin{array}{c}\text { Degree of } \\
\text { Freedom }\end{array}$ & $\begin{array}{c}\text { Significance } \\
\text { Level }\end{array}$ & $\begin{array}{c}\text { Exp } \\
(\mathrm{B})\end{array}$ \\
\hline X1 & -7.73 & 11.77 & 0.43 & 1.00 & 0.51 & 0.00 \\
X2 & -0.87 & 0.82 & 1.12 & 1.00 & 0.29 & 0.42 \\
X3 & -2.78 & 2.54 & 1.19 & 1.00 & 0.28 & 0.06 \\
X4 & -0.10 & 8.03 & 0.00 & 1.00 & 0.99 & 0.91 \\
X5 & 0.94 & 1.59 & 0.35 & 1.00 & 0.55 & 2.55 \\
X6 & -2.23 & 2.89 & 0.60 & 1.00 & 0.44 & 0.11 \\
X7 & -3.95 & 3.92 & 1.02 & 1.00 & 0.31 & 0.02 \\
X8 & -3.73 & 7.41 & 0.25 & 1.00 & 0.61 & 0.02 \\
X9 & 0.29 & 0.63 & 0.21 & 1.00 & 0.65 & 1.33 \\
X10 & -1.12 & 2.18 & 0.26 & 1.00 & 0.61 & 0.33 \\
X11 & 0.11 & 1.06 & 0.01 & 1.00 & 0.92 & 1.11 \\
X12 & 0.31 & 5.97 & 0.00 & 1.00 & 0.96 & 1.37 \\
X13 & 0.68 & 4.97 & 0.02 & 1.00 & 0.89 & 1.96 \\
X14 & -0.90 & 0.35 & 6.50 & 1.00 & 0.01 & 0.41 \\
X15 & -1.36 & 0.90 & 2.26 & 1.00 & 0.13 & 0.26 \\
X16 & -3.74 & 1.89 & 3.92 & 1.00 & 0.05 & 0.02 \\
X17 & 0.50 & 0.37 & 1.81 & 1.00 & 0.18 & 1.65 \\
X18 & 0.03 & 0.02 & 2.75 & 1.00 & 0.10 & 1.04 \\
X19 & 0.00 & 0.02 & 0.00 & 1.00 & 0.97 & 1.00 \\
\hline X20 & 0.00 & 0.00 & 1.97 & 1.00 & 0.16 & 1.00 \\
\hline Constant & 5.13 & 3.00 & 2.92 & 1.00 & 0.09 & 169.45 \\
\hline
\end{tabular}

In the final step, the correctness of model has been determined by deploying model in the following table 4. This means that if a customer is good at settling accounts, the model can predict it, if the correctness is equal to 75 percent, and in case of a customer tardy in settling accounts, the model can predict it if the correctness value is equal to 61 percent. This model can predict the behavior of customers in general at the correctness level of 69 percent.

Table 4

The Accuracy of Logit Model

\begin{tabular}{|c|c|c|c|c|}
\hline \multirow{2}{*}{ Steps } & \multirow[t]{2}{*}{ Observed } & \multicolumn{2}{|c|}{ Prediction } & \multirow{2}{*}{$\begin{array}{l}\text { Percent of } \\
\text { Correctness }\end{array}$} \\
\hline & & $\begin{array}{c}\text { Good at Settling } \\
\text { Accounts }\end{array}$ & $\begin{array}{c}\text { Tardy in Settling } \\
\text { Accounts }\end{array}$ & \\
\hline \multirow[t]{3}{*}{ Step 1} & Good & 74 & 7 & 91.36 \\
\hline & Tardy & 37 & 19 & 33.93 \\
\hline & & & & 67.88 \\
\hline \multirow[t]{3}{*}{ Step 2} & Good & 68 & 13 & 83.95 \\
\hline & Tardy & 21 & 35 & 62.50 \\
\hline & & & & 75.18 \\
\hline \multirow[t]{3}{*}{ Step 3} & Good & 65 & 16 & 80.25 \\
\hline & Tardy & 24 & 32 & 57.14 \\
\hline & & & & 70.80 \\
\hline \multirow[t]{3}{*}{ Step 4} & Good & 63 & 18 & 77.78 \\
\hline & Tardy & 23 & 33 & 58.93 \\
\hline & & & & 70.07 \\
\hline \multirow[t]{2}{*}{ Step 5} & Good & 61 & 20 & 75.31 \\
\hline & Tardy & 22 & 34 & 60.71 \\
\hline
\end{tabular}

The results of the five-step estimation have been summarized in the following Table 5: 
Table 5

The summery of Logit model estimations in five steps

\begin{tabular}{cccccccc}
\hline Steps & Variables & Coefficient & $\begin{array}{c}\text { Deviation } \\
\text { from } \\
\text { Standard }\end{array}$ & Parent & $\begin{array}{c}\text { Degree of } \\
\text { Freedom }\end{array}$ & $\begin{array}{c}\text { Significance } \\
\text { Level }\end{array}$ & Exp (B) \\
\hline 1 & X10 & -4.86 & 1.30 & 13.91 & 1.00 & 0.00 & 0.01 \\
\hline 2 & Constant & -0.08 & 0.20 & 0.15 & 1.00 & 0.70 & 0.92 \\
& X10 & -4.50 & 1.33 & 11.39 & 1.00 & 0.00 & 0.01 \\
& X14 & -0.61 & 0.25 & 5.86 & 1.00 & 0.02 & 0.55 \\
\hline 3 & Constant & 0.51 & 0.31 & 2.76 & 1.00 & 0.10 & 1.67 \\
\hline & X10 & -4.36 & 1.36 & 10.35 & 1.00 & 0.00 & 0.01 \\
& X14 & -0.78 & 0.28 & 7.68 & 1.00 & 0.01 & 0.46 \\
& X16 & -2.67 & 1.22 & 4.79 & 1.00 & 0.03 & 0.07 \\
& Constant & 1.12 & 0.42 & 7.07 & 1.00 & 0.01 & 3.08 \\
\hline & X8 & -8.74 & 4.16 & 4.42 & 1.00 & 0.04 & 0.00 \\
& X10 & -1.29 & 1.66 & 0.61 & 1.00 & 0.44 & 0.27 \\
& X14 & -0.78 & 0.28 & 8.02 & 1.00 & 0.00 & 0.46 \\
& X16 & -3.19 & 1.27 & 6.33 & 1.00 & 0.01 & 0.04 \\
\hline 5 & Constant & 1.43 & 0.45 & 9.97 & 1.00 & 0.00 & 4.18 \\
\hline & X8 & -10.98 & 3.10 & 12.52 & 1.00 & 0.00 & 0.00 \\
& X14 & -0.80 & 0.27 & 8.53 & 1.00 & 0.00 & 0.45 \\
& X16 & -3.38 & 1.24 & 7.50 & 1.00 & 0.01 & 0.03 \\
\hline & Constant & 1.52 & 0.44 & 11.93 & 1.00 & 0.00 & 4.57 \\
\hline
\end{tabular}

In the final step, there are three significant variables in the model including the variable of net profit to assets $\left(\mathrm{X}_{8}\right)$, sales to assets $\left(\mathrm{X}_{14}\right)$, and creditors to sales $\left(\mathrm{X}_{16}\right)$. The model has been provided as follows:

$$
E\left(\frac{y_{i}}{n_{i}}\right)=p_{i}=\frac{\operatorname{Exp}\left(1.52-10.98 X_{8}-0.8 X_{14}-3.38 X_{16}\right)}{1+\operatorname{Exp}\left(1.52-10.98 X_{8}-0.8 X_{14}-3.38 X_{16}\right)}
$$

\section{E) The Comparison of two Models}

The correctness level of prediction in multistep regression is equal to 73.7 percent $(21.9+51.8)$, and the correctness level of prediction in logit regression is equal to 80.3 percent $(29.9+50.4)$. Therefore, the correct prediction in logit regression is up to 7 percent more accurate than that of multistep regression.

\section{Conclusion}

The results of this research have shown that financial ratios can forecast credit risk of the applicants of facilities. Moreover, the prediction accuracies of linear regression and logit regression are not significantly different from each other, and both models can be applied. However, logit model is more accurate in the prediction of credit risk and more consistent with the reality. Therefore, the hypothesis of this research stating, "The logit model can predict credit risk in the field of research better”, is confirmed.

\section{References}

Altman, E. (1968). Financial Ratios, Disarmament Analysis and the Prediction of Corporate Bankruptcy. Journal of Finance, 23, 589-609. 
Beaver W.H. (1966). Financial ratios as predictors of failure. Journal of Accounting Research, 18(4), 71-11.

Basel Committee On Banking Regulation \& supervisory practices (2000).

Chateau, D. P. (2009). Approach for credit risk modeling in banks and insurance. International Review of Financial Analysis, 18(5), 260-270.

Dun \& Bradstreet (1998). Bankruptcy insolvency accounting practice and procedure. Journal of Financial, 13, 21-41.

Fallah Shams, M. (2005). The Management of Credit Risk in Banks and Financial Institutes. (Concepts and Models). Economic Sciences Faculty Press

Fiori, R., Foglia, A., Iannotti, S. (2008). Estimating macroeconomic credit risk and sectoral default rate correlations for the Italian Banks. Journal of Financial, 17(3), 405-417.

Greuning, H. \& Bratanovice, S.B. (2003). Analyzing and managing banking risk. Journal of work bank, 1-6.

Heidarzadeh, A. (2008). The evaluation of the solvency of customers in the repayment of their liabilities based on Altman Z-Score model. Unpublished master dissertation. Tehran University ,Iran

Hosmer, D. W., \& Lemeshow, S. (2004). Applied logistic regression (Vol. 354). Wiley-Interscience.

Khani, M. (2007). The Design and Explanation of Credit Risk Model in the Banking System of Iran. unpublished master dissertation” Tehran University ,Iran

Latifi, H. (2004). A Study of the Relation between the Indices of Credit Risk and on time Repayment of the Liabilities of Bank Customers. Unpublished Master Dissertation. Tehran University ,Iran

Lopez, J. (2009). Evaluating credit risk models. Journal of Banking \& Finance, 33(2), 281-299.

Mansouri, A., Azar, A. (2002). The Explanation of an Efficient Model of Bank Facilities Allocation based on Neural Network Approach and Logistic Regression. Nashr Modares Journal, 3(6), 125146.

Mohammadkhan, M., Esmaili, M.A., \& Yarahmadi, M. (2008). The Design of a Evaluation Model of the Credit Risk of Bank Customers using Logistic Regression Model. $6^{\text {th }}$ International Conference of Industrial Engineering

Pasiouras, F. (2008). Estimating the technical and scale efficiency of Greek commercial banks: the impact of credit risk, off-balance sheet activities, and international operations. Research in International Business and Finance, 22(3), 301-318.

Sabzevari, H. (2009). The estimation and comparison of Logit credit rating model and hierarchical analysis method. unpublished master dissertation, Tehran University ,Iran

Soltani, M. (2000). A Study of the Factors Effective in the Deferred Claims of Bank Melli of Mazandaran Province. unpublished master dissertation, Tehran University, Iran.

Stringa, M. \& Drehmann, M. (2010) credit risk modeling : A new approach. Journal of Banking \& Finance, 34(4), 713-729.

Vedadi, A. (2004). A Study of the Credential Behavior of the Customers Receiving Facilities based on Credit Rating Neural Networks. Unpublished PhD Dissertation, Tehran University ,Iran

Zekavat, S. M. (2003). Models of Credit Risk of the Customers of Bank Tose'eh Saderat (Export Development Bank) of Iran. unpublished master dissertation, Tehran University ,Iran 